Volume 2 Nomor 1 Januari 2022: Halaman: $40-44$

Doi: $10.47650 /$ pjphsr.v2i1.343

ISSN (Online): 2777-1296

OJS: http://journal.unpacti.ac.id/index.php/pjphsr

\title{
FAMILY SOCIAL SUPPORT FOR THE HYPEREMESIS GRAVIDARUM INCIDENT AT LABUANG BAJI REGIONAL HOSPITAL
}

\section{Dukungan Sosial Keluarga Terhadap Kejadian Hyperemesis Gravidarum Di RSUD Labuang Baji}

\section{Ani}

Sekolah Tinggi Ilmu Kesehatan Graha Edukasi Makassar

*Alamat Korespondensi: safaniani@gmail.com

\begin{tabular}{l}
\hline Article Info \\
\hline Article History \\
Received: 27 Dec 2021 \\
Revised : 05 Jan 2022 \\
Accepted : 10 Jan 2022
\end{tabular}

Keywords :

Hyperemesis gravidarum, social support, Expectant mother, Family

\begin{abstract}
ABSTRAK
Hyperemesis gravidarum is the incidence of nausea and vomiting by pregnant women more than 10 times for $2 \times 24$ hours. There are $65 \%$ of families who do not understand how social support should be received by pregnant women with hyperemesis gravidarum. This study aims to determine the level of social family support for pregnant women who experience Hyperemesis Gravidarum. This is a quantitative study with a descriptive-analytical model and a cross-sectional approach at the Labuang Baji Regional Hospital, Makassar, March 21-22, 2017. The population and sample were 80 people. Using the total sampling method, the sampling was done by accident. Family social support has a relevant relationship with the level of risk of hyperemesis gravidarum. Statistically, the P-value is = $0.026<\alpha=0.05$. Family support is very helpful in reducing the risk of hyperemesis gravidarum in pregnant women.
\end{abstract}

Hyperemesis gravidarum adalah kejadian mual dan muntah oleh ibu hamil sebanyak > 10 kali selama $2 \times 24$ jam. Terdapat $65 \%$ kelurga yang tidak memahami bagaimana dukungan sosial yang harus di dapatkan oleh ibu hamil yang mengalami Hyperemesis Gravidarum. Penelitian ini bertujuan untuk mengetahui tingkat dukungan sosial keluarga terhadap ibu hamil yang mengalami Hyperemesis Gravidarum. Penelitian ini merupakan penelitian kuantitatif dengan model Descriptive Analitik, pendekatan cross-sectional, di Rumah Sakit Umum Daerah Labuang Baji, Makassar, 21 Maret-21 Mei Tahun 2017. Populasi dan sampel sebanyak 80 orang dengan metode total sampling, pengambilan sampel dilakukan secara accidental. dukungan sosial kelurga memiliki hubungan yang relevan dengan tingkat risiko Hyperemesis Gravidarum, secara statistik di dapatkan nilai $P=0,026<\alpha=0,05$. Dukungan keluarga sangat membantu untuk mengurangi tingkat risiko Hyperemesis gravidarum pada ibu hamil. 


\section{PENDAHULUAN}

Hyperemesis gravidarum merupakan keadaan mual disertai muntah yang di alami oleh ibu hamil selama $2 \times 12$ jam dengan frekuensi lebih dari 10 kali, kondisi tersebut umumnya di jumpai pada usia kehamilan 2-3 Bulan (Susilawati and Erlyna Evasari, 2017). Keadaan hyperemesis gravidarum yang tidak mendapatkan perhatian dari pihak kelaurga maka dapat mengakibatkan kekurangan nutrisi dari ibu hamil dan secara berkepanjangan akan menimbulkan risiko pada janin ibu (Susanti, Firdayanti and Haruna, 2019).

Menurut Trian dan Hastuti dalam penelitiannya bahwa ibu yang mengalami Hyperemesis gravidarum, sebagian besar mengatakan mengalami kehilangan nafsu makan lemas dan panas hingga menjalani perawatan di rumah sakit (Triana and Hastuti, 2020).

Dukungan anggota keluarga merupakan salah satu unsur yang sangat penting untuk membantu ibu hamil yang mengalami hyperemesis gravidarum, sehingga meningkatkan rasa percaya diri dan motivasi ibu hamil, dukungan sosial yang utama dari pihak keluarga serumah (Rofi'ah, Widatiningsih and Arfiana, 2019).

Berdasarkan data sekunder yang diperoleh dari RSUD Labuang Baji di ketahui jumlah ibu hamil yang mengalami Hyperemesis Gravidarum hingga mendapatkan perawatan yaitu sejak per bulan Desember 2015 sebanyak 26,21\% dari 1.362 orang ibu hamil hingga Desember 2016 sebanyak 28\% dari 1.347 orang ibu hamil, hal ini berarti bahwa setiap tahunnya ibu hamil harus mendapatkan dukungan sosial dari kelurga. Studi pendahuluan yang telah di lakukan pada tanggal 21 sampai dengan 25 maret 2017 di dapat informasi bahwa dari 15 informan ibu hamil hyperemesis terdapat $65 \%$ kelurga yang tidak memahami bagaimana dukungan sosial yang harus di dapatkan oleh ibu hamil yang mengalami Hyperemesis Gravidarum.

Oleh karena itu penelitian ini bertujuan untuk mengetahui tingkat dukungan sosial keluarga terhadap ibu hamil yang mengalami Hyperemesis Gravidarum.

\section{BAHAN DAN METODE}

Penelitian ini merupakan penelitian kuantitatif dengan model Descriptive Analitik dengan pendekatan cross-sectional. Penelitian ini telah dilaksanakan di Rumah Sakit Umum Daerah Labuang Baji, Makassar, Pada tanggal 21 Maret sampai dengan tanggal 21 Mei Tahun 2017. Populasi dalam penelitian ini sebanyak 80 orang kelaurga pendamping ibu hamil, baik suami, orang tua dan saudara. Sampel dalam penelitian sebanyak 80 orang ditentukan berdasarkan metode total sampling, pengambilan sampel dilakukan secara accidental. Pengumpulan data dilakukan menggunakan cara observasi dengan teknik wawancara menggunakan kuesioner secara langsung. Analisis data dilakukan secara statistik berdasarkan Chi-square. Penyajian data menggunakan tabel dan narasi.

\section{HASIL}

Penelitian ini dilakukan di RSUD Labuang Baji Makassar dengan pengumpulan data secara primer yaitu mengambil langsung data pada sampel/responden sebanyak 80 orang. Yang kemudian diperoleh hasil sebagai berikut:

Tabel 1. Distribusi frekuensi responden berdasarkan umur dan pendidikan.

\begin{tabular}{llc}
\hline \multicolumn{2}{c}{ Karakteristik Responden } & n (\%) \\
\hline Umur & 20-30 Tahun & $34(42,5 \%)$ \\
\multirow{4}{*}{ Pendidikan } & $>$ 30 Tahun & $46(57,5 \%)$ \\
& SD & $18(22,5 \%)$ \\
& SMP & $22(27,5 \%)$ \\
& SMA & $26(32,5 \%)$ \\
\hline & Sarjana & $14(17,5 \%)$ \\
\hline
\end{tabular}

Sumber: Data Primer, 2017

Berdasarkan data pada tabel 1 diketahui bahwa pendamping ibu hamil dengan Hyperemesis Gravidarum yang mengalami perawatan, sebagian besar telah berumur lebih dari 30 tahu, dan rata - rata pendidikan yang di miliki yaitu Sekolah Menengah Pertama (SMP) dan Sekolah Menengah Atas (SMA). 


\section{PEMBAHASAN}

Temuan penelitian ini mempertegas bahwa dukungan sosial kelurga memiliki hubungan yang relevan dengan tingkat risiko Hyperemesis Gravidarum. Ibu hamil yang mengalami Hyperemesis Gravidarum belum mendapatkan dukungan sosial dengan baik dari keluarga, berbeda dengan ibu hamil yang tidak mengalami Hyperemesis Gravidarum.

Pada penelitian ini didapatkan bahwa keluarga ibu hamil yang tidak memberikan dukungan sosial karena beranggapan bahwa hal tersebut adalah hal yang lazim dirasakan oleh ibu hamil, serta keluarga tidak cukup mengetahui halhal yang harus di berikan kepada ibu hamil yang mengalami Hyperemesis Gravidarum, sehingga kejadian tersebut menjadi berlebihan dan berdampak pada ibu hamil yang harus di berikan perawatan di rumah sakit.

Dukungan kelaurga seperti dukungan sosial sangat membantu ibu hamil dalam menyesuaikan diri menghadapi tekanan dan konflik yang timbul akibat evolusi fisik serta psikologis semasa hamil, tinggi rendahnya penyesuaian ibu selama kehamilan relevan dengan dukungan keluarga yang di butuhkan (Astuti, Santosa and Utami, 2020).

\section{Tabel 2. Distribusi Dukungan Sosial Keluarga Terhadap ibu hamil Hyperemesis Gravidarum Pada} Ibu Hamil di RSUD Labuang Baji Makassar.

\begin{tabular}{|c|c|c|c|c|c|c|c|}
\hline \multirow{3}{*}{$\begin{array}{c}\text { Dukungan Sosial } \\
\text { Kelurga }\end{array}$} & \multicolumn{4}{|c|}{ Hyperemesis Gravidarum } & \multirow{2}{*}{\multicolumn{2}{|c|}{ Total }} & \multirow{3}{*}{$\mathbf{p}$} \\
\hline & \multicolumn{2}{|c|}{ Tidak } & \multicolumn{2}{|c|}{ Ya } & & & \\
\hline & $\Sigma$ & $\%$ & $\Sigma$ & $\%$ & $\Sigma$ & $\%$ & \\
\hline Tidak Mendukung & 12 & 40,0 & 18 & 60,0 & 30 & 100 & \multirow{3}{*}{0,026} \\
\hline Mendukung & 40 & 80,0 & 10 & 20,0 & 50 & 100 & \\
\hline Total & 52 & 56,0 & 28 & 35,0 & 80 & 100 & \\
\hline
\end{tabular}

Sumber: Data Primer, 2017

Hasil penelitian serupa juga mengungkapkan bahwa Kondisi Hyperemesis Gravidarum seringkali di anggap sebagai hal yang biasa terjadi dalam keluarga ibu hamil, sesungguhnya keadaan tersebut lebih berbahaya atau lebih parah dan lebih dari pada morning sickness. Hyperemesis Gravidarum bukan hanya memiliki risiko yang berdampak pada ibu hamil, namun memiliki risiko yang jauh lebih berbahaya karena akan berdampak langsung kepada janin hingga terjadi abortus atau keguguran, prematur, BBLR dan yang paling ringan yaitu mal-formasi janin (Yusuf and Sri, 2018).

Hasil penelitian Susilawati dan Erlyna menujukkan bahwa, secara umum faktor psikologik menjadi aspek yang sangat penting pada saat Hyperemesis Gravidarum, ibu yang sedang dalam proses kehamilan rentan terhadap konflik mental yang dapat memicu meningkatnya mual dan muntah yang di tunjukkan sebagai bentuk kesukaran hidup (Susilawati and Erlyna Evasari, 2017).
Sitti Roif'ah dkk, dalam hasil penelitiannya mengungkapkan, masih terdapat persepsi Hyperemesis Gravidarum disebabkan karena bawaan bayi serta turunan dari keluarga, sehingga keluarga cenderung membiarkan keadaan tersebut dan tidak siaga untuk melakukan upaya pencegahan serta pengobatan terhadap gejala yang di alami oleh ibu hamil, karena menilai bahwa hal tersebut tidak akan hilang sebelum masanya selesai hingga akibat yang fatal dan risiko yang tinggi dialami oleh ibu dan janinnya (Rofi'ah, Widatiningsih and Arfiana, 2019).

Hasil penelitian serupa menunjukkan hubungan antara dukungan keluarga khususnya suami terhadap tingkat risiko kejadian Hyperemesis Gravidarum pada ibu hamil, yaitu semakin besar perhatian yang diberikan oleh keluarga maka semakin rendah risiko Hyperemesis Gravidarum dan semakin rendah perhatian keluarga maka semakin tinggi pula risiko Hyperemesis Gravidarum yang di alami oleh ibu hamil (Suwardi and Siregar, 2019). 
Pada hasil penelitian Firdayanti dan Haruna mengemukakan fakta yang berbeda, bahwa hyperemesis gravidarum adalah kondisi tubuh yang meningkatkan hormon estrogen dan HCG (Hormon Chorionic Gonadotrophin) dalam serum, sehingga ibu hamil mengalami mual dan muntah selama menjalani proses kehamilan (Susanti, Firdayanti and Haruna, 2019).

Subriani pada hasil penelitiannya menunjukkan bahwa Hyperemesis Gravidarum justru lebih banyak terjadi karena faktor Mola Hidatidosa dan Gemelli, karena keadaan tersebut dapat mengakibatkan pembentukan hormon Chorionic Gonadotropin (HCG) secara berlebihan sehingga memicu terjadinya hyperemesis gravidarum pada ibu hamil (Subriani, 2018). hyperemesis gravidarum lebih sering di alami oleh ibu yang mengalami kehamilan ganda kerana kadar hormon Chorionic Gonadotropin yang terus meningkat (Abidah and Fauziyatun, 2019).

Hasil penelitian serupa menjelaskan bahwa hyperemesis gravidarum yang di rasakan oleh ibu hamil disebabkan dari hormonal, pola makan, kehamilan tidak diinginkan, psikologis dan perhatian serta harmonisasi yang lebih dari keluarga (Setianingrum, Tsani and Irmania, 2019).

Berdasarkan hasil penelitian yang di dapatkan maka dapat di asumsikan bahwa sebagian besar keluarga ibu hamil belum memiliki pengetahuan yang cukup terkait Hyperemesis Gravidarum, sehingga lalai dalam memperhatikan ibu yang sedang dalam proses kehamilan, dan tidak mampu mencegah Hyperemesis Gravidarum agar tidak semakin bertambah parah. hal tersebut akan berdampak pada risiko yang lebih tinggi apabila terus dibiarkan.

Dukungan keluarga kepada ibu hamil yang Hyperemesis gravidarum dapat dilakukan dengan memberikan perhatian dan harmonisasi yang lebih serta menjaga pemenuhan kebutuhan nutrisi ibu, menjaga pola makan 3 x sehari, asupan makanan bergizi dan berserat tinggi, waktu isterahat yang cukup bagi ibu hamil juga harus di perhatikan oleh kelurga yaitu antara 7-8 jam pada waktu malam dan 1-2 jam pada waktu siang hari. Hal tersebut sangat perlu di perhatikan karena sangat berpengaruh terhadap kesehatan ibu dan janin dan kelurga harus terus mengevaluasi hal-hal tersebut dan berkonsultasi ke dokter atau layanan kesehatan.

Mempertahankan hidrasi pada ibu hamil Hyperemesis gravidarum penting untuk menjaga nutrisi dalam jangka pendek, sebelum mendapatkan tambahan cairan intra vena multivitamin (Marlin, 2018).

\section{KESIMPULAN DAN SARAN}

Penelitian ini menyimpulkan bahwa dukungan keluarga sangat membantu untuk mengurangi tingkat risiko Hyperemesis gravidarum pada ibu hamil, karena secara umum ibu hamil harus mendapatkan dukungan keluarga khsusnya yang mengalami Hyperemesis gravidarum tentu sangat memerlukan support yang lebih dari pihak keluarga baik secara psikologi maupun perhatian-perhatian lainnya.

$$
\text { Olehnya itu, penelitian ini }
$$
merekomendasikan kepada seluruh pihak keluarga terdekat ibu hamil agar memperhatikan kebutuhan-kebutuhan ibu hamil yang mengalami Hyperemesis gravidarum terutama kebutuhan nutrisi ibu, pola makan $3 \times$ sehari, asupan makan bergizi dan berserat tinggi, dan waktu istrahat yang cukup pada siang dan malam hari, agar tidak berakibat terhadap ibu dan janinnya, serta intensitas untuk berkonsultasi ke dokter atau layanan kesehatan harus di tingkatkan.

\section{DAFTAR PUSTAKA}

Abidah, S. N. and Fauziyatun, F. N. (2019) 'FaktorFaktor Yang Berhubungan Dengan Hiperemesis Gravidarum Pada Ibu Hamil Di $\mathrm{Rb}$ Zakat Surabaya', Embrio, Jurnal Kebidanan, 11(2), pp. 94-101. https://doi.org/10.36456/embrio.vol11.no 2.a2045.

Astuti, A. B., Santosa, S. W. and Utami, M. S. (2020) 'HUBUNGAN ANTARA DUKUNGAN KELUARGA DENGAN PENYESUAIAN DIRI PEREMPUAN PADA KEHAMILAN PERTAMA', JURNAL PSIKOLOGI, (2), pp. 84-95. 
Marlin, D. (2018) 'Hiperemesis Gravidarum : Asesmen dan Asuhan Kebidanan', Scientia Journal, 7(2), pp. 151-158. Available at: https://www.neliti.com/publications/2864 $45 /$.

Rofi'ah, S., Widatiningsih, S. and Arfiana, A. (2019) 'Studi Fenomenologi Kejadian Hiperemesis Gravidarum Pada Ibu Hamil Trimester I', Jurnal Riset Kesehatan, 8(1), p. 41. https://doi.org/10.31983/jrk.v8i1.3844.

Setianingrum, P. D., Tsani and Irmania, F. (2019) 'HIPEREMESIS GRAVIDARUM PADA IBU HAMIL DI KLINIK BIDAN SUPRIYATI SRIBIT BERBAH SLEMAN', Jurnal IImiah IImu Keperawatan dan Ilmu Kesehatan Masyarakat, 14(1). https://doi.org/10.32504/sm.v14i1.108

Subriani (2018) 'Hubungan Mola Hidatidosa dan Gemelli Terhadap Hiperemesis Gravidarum di RSUD Haji Makassar', Jurnal Kesehatan Delima Pelamonia, 2(1), pp. 10-17. https://doi.org/10.37337/jkdp.v2i1.53

Susanti, E., Firdayanti, F. and Haruna, N. (2019) 'Manajemen Asuhan Kebidanan Antenatal Pada Ny "S" dengan Hiperemesis Gravidarum Tingkat II di Rs TNI Angkatan Laut Jala Ammari', Jurnal Midwifery, 1(2), pp. 79-91. doi: 10.24252/jmw.v1i2.10557. https://doi.org/10.24252/jmw.v1i2.10557

Susilawati and Erlyna Evasari (2017) 'Hubungan Gravida, Umur dan Pendidikan Ibu dengan Hiperemesis Gravidarum', Jurnal Obstretika Scientia, 4, pp. 435-452.

Suwardi, S. and Siregar, D. A. (2019) 'Hubungan Paritas, Dukungan Suami Dan Dukungan Keluarga Pada Ibu Hamil Dengan Hiperemesis Gravidarum', Jurnal Ilmiah Ilmu Kesehatan: Wawasan Kesehatan, 5(2), pp. 224-231. doi: 10.33485/jiikwk.v5i2.132. https://doi.org/10.33485/jiikwk.v5i2.132

Triana, A. and Hastuti, Y. D. (2020) 'Tingkat Hiperemesis Gravidarum Pada Ibu Hamil Trimester I Di Kabupaten Kendal', Jurnal Kebidanan Malakbi, 1(2), pp. 50-56. https://doi.org/10.33490/b.v1i2.300

Yusuf, N. and Sri, W. (2018) 'FAKTOR-FAKTOR YANG MEMPENGARUHI KEJADIAN HIPEREMESIS GRAVIDARUM (Studi Kasus di Rumah Sakit Umum Daerah dr Zainoel Abidin Banda Aceh)', Majalah Kesehatan Masyarakat Aceh (MaKMA), 1(2), pp. 94-100. Available at:

http://ojs.serambimekkah.ac.id/MaKMA/a rticle/view/823/702. 